J. Perinat. Med. 15 (1987) 3

\title{
A comparative study of three indices of umbilical blood flow in relation to prediction of growth retardation
}

\author{
Léon G. M. Mulders ${ }^{1}$, Pieter F. F. Wijn², Henk W. Jongsma1 ${ }^{1}$, and Peter R. \\ Hein ${ }^{1}$
}

${ }^{1}$ Department of Obstetrics and Gynecology and ${ }^{2}$ Clinical Vascular Laboratory, St. Radboud Hospital, Catholic University of Nijmegen, The Netherlands

\section{Introduction}

In the literature of Doppler flow velocity waveform (FVW) analysis of the umbilical artery, several authors describe characteristic changes (a diminished end-diastolic flow) in the FVW in combination with intrauterine growth retardation (IUGR) [1, 2, 3, 6, 12, 13, 17]. A decreased end-diastolic flow is reported to be indicative of increased fetal placental resistance. Different indices, originally introduced to evaluate the pulsatility of the arterial waveforms of different vascular beds in adults $[4,5$, 10], have been proposed in order to assess the vascular bed resistance downstream the umbilical artery (figure 1):

- A/B-ratio [5], in American literature S/D ratio, is defined as peak-systolic flow (A) divided by end-diastolic flow (B) $[3,13,16$, 17].

- Resistance Index (RI) [10], is defined as peak-systolic flow (A) minus end-diastolic flow (B) divided by peak-systolic flow, $((\mathrm{A}-\mathrm{B}) / \mathrm{A})$. In his study CAMPBell [1] reported good correlations between elevated RI of both the fetal descending aorta and arcuate arteries and complicated pregnancies.

- Pulsatility Index (PI) [4], is defined as the difference between peak-systolic and enddiastolic flow, divided by the mean flow

\section{Curriculum vitae}

LÉON MULDERS, was born in 1955 in Zevenbergen, The Netherlands and studied general medicine at the Catholic University of Nijmegen, from which he graduated in 1982.

From 1982-1984 he worked in the Departments of Surgery and Obstetrics and Gynecology of Groot Ziekengasthuis in 's-Herto-

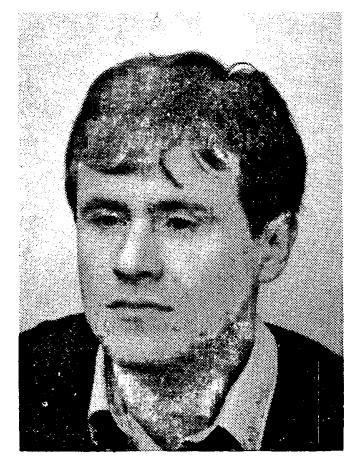

genbosch, The Netherlands. At the end of 1984 he started his research work in the field of umbilical and uterine blood flow at the Department of Obstetrics and Gynecology of Sint Radboud University Hospital in Nijmegen, The Netherlands. As of August 1985 he has been resident at the Department of Obstetrics and Gynecology of Groot Ziekengasthuis in 's-Hertogenbosch, The Netherlands.

$((\mathrm{A}-\mathrm{B}) /$ mean $)$. Good negative correlations between fetal growth and the PI of the umbilical artery [2, 11, 12] and the fetal descending aorta [6] are reported, even weeks to months before IUGR was suspected clinically.

The aim of this study was to evaluate, which of the above mentioned indices correlates best with IUGR. Furthermore, the validity of these indices to predict IUGR has been investigated. 


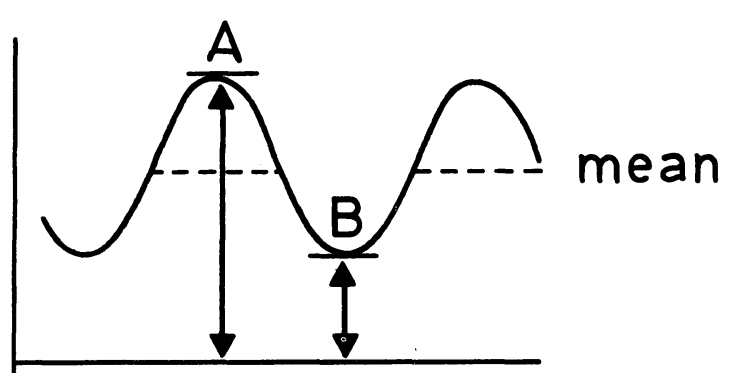

$A B$ ratio

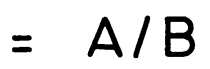

Resistance index $=\frac{A-B}{A}$

Pulsatility index $=\frac{A-B}{\text { mean }}$

Figure 1. Three indices of qualitative blood flow measurements of the umbilical artery.

\section{Materials and methods}

The studied group consisted of 48 pregnant women. Thirty were patients, admitted to the obstetrical department with suspected IUGR or hypertension. The other 18 women attended the antepartum clinic of St. Radboud Hospital with an uncomplicated pregnancy. All pregnancies were singleton and accurately dated by analysis of menstrual history and first trimester ultrasonographic crown-rump length measurements.

Umbilical artery Doppler spectra were recorded at a gestational age of $34 \pm 2$ weeks with the pregnant woman in a left lateral tilt position. The position of the umbilical cord was located with a linear-array echo imaging system (Philips Diagnost R 1000). Doppler spectra were obtained with a bidirectional continuous wave (CW) unit (Medasonics), using a 5- or $8-\mathrm{MHz}$ probe in combination with a Radionics SA 8000 spectrum analyzer with the wall thumb filter switched off (lowest detectable frequency: 73 $\mathrm{Hz}$ ). Doppler spectra of blood flow do not contain one frequency as a function of time but a complete frequency spectrum, due to the different velocities of the erythrocytes in the insonated blood vessel. They are represented in a gray scale image in which "time" is represented on the horizontal axis, Doppler frequency shift on the vertical axis and the power of the received Doppler signals in the gray scale (figure 2). Doppler spectra show bidirectional information of the blood velocity, both advancing flow towards and receding flow away from the probe (figure 2). Usually in the umbilical artery there is only advancing flow, where receding flow in the same spectrum is in most cases due to Doppler shifts from the umbilical vein, which is insonated at the same time. Receding arterial flow, due to a very high fetal placental resistance, is a rarely described phenomenon [18] and can easily be distinguished from venous flow, due to its pulsatile character.

The real-time display of the Doppler spectra helps to optimize the insonation of the vessel. The pencil-probe is manipulated untill best quality signals are obtained, which are defined by the absence of high intensity spots in the gray scale figure near the baseline (indicative for vessel wall movements) and a concentration of high intensity near the maximum frequency (indicative for insonating the center of the vessel) [19]. The pattern of the umbilical artery FVW is easily recognized and distinguished from other fetal Doppler spectra. With the 5$\mathrm{MHz}$ probe the maximum Doppler frequency shift does not usually exceed $4 \mathrm{kHz}$. Therefore, in all recordings the frequency range $-2,5$ to $+7,5 \mathrm{kHz}$ was used (figure 2).

Only recordings during fetal apnea were accepted, since considerable distortion of the Doppler spectrum can be noticed during fetal breathing or hiccups [8]; this was checked echoscopically immediately before and after the flow measurements. Once optimal spectra were visible on the display of the spectrum analyzer, the image of the last 4 seconds was freezed. Starting with the first complete heart beat, the complete Doppler spectrum of 125 spectral lines with a resolution of $8.3 \mathrm{~ms}$ (total duration $1.04 \mathrm{~s}$ ) was fed via a serial line (RS 232) into a 


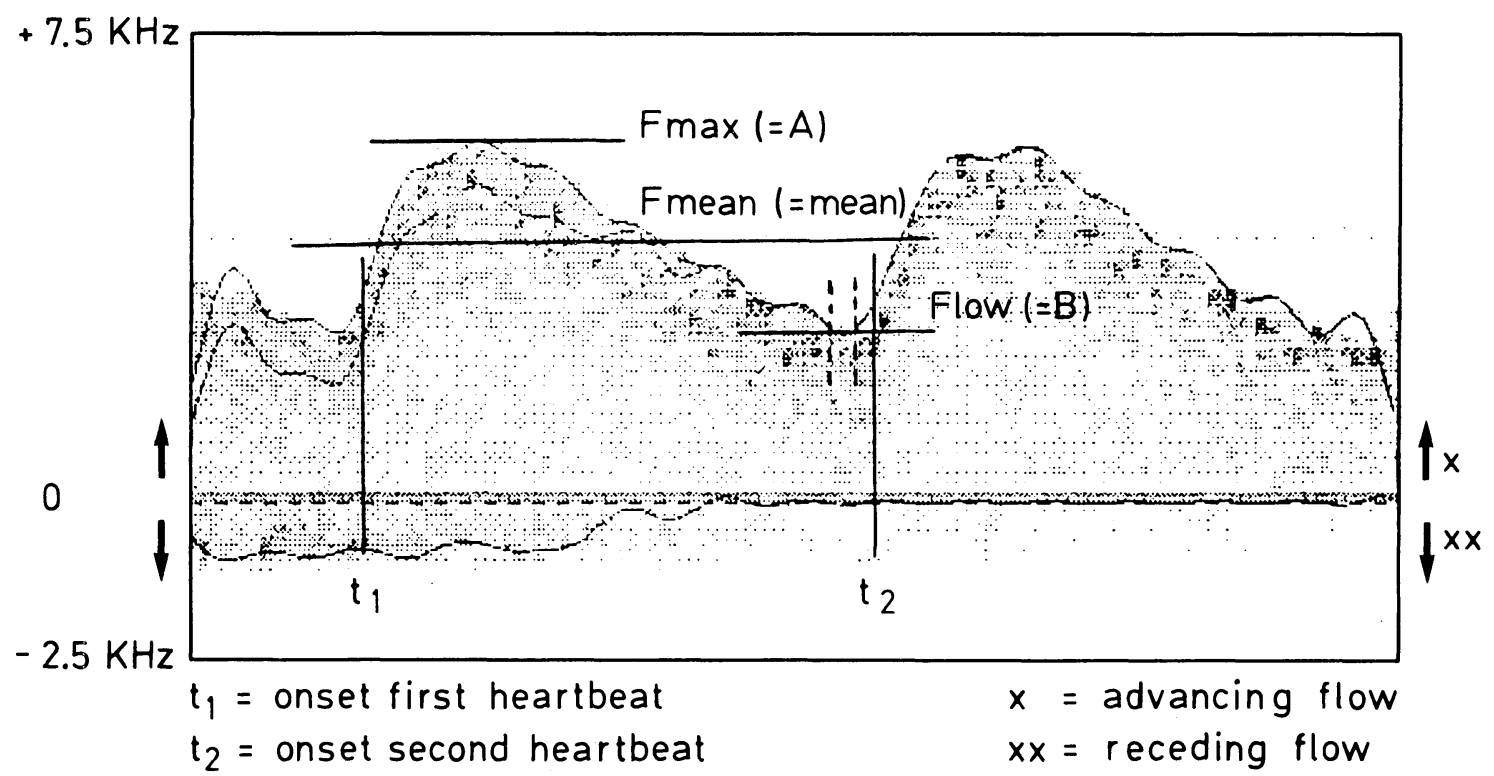

Figure 2. Gray scale image of Doppler spectra of the umbilical artery, in which time is on the horizontal axis, Doppler frequency shift on the vertical axis and the power of the received Doppler signals in the gray scale. Advancing flow towards the probe above the horizontal axis, receding flow beneath the axis. In the first part of the spectrum the umbilical vein is insonated together with the umbilical artery: note the maximum frequency (MAX-) curve of this venous flow beneath the axis. $F_{\max }(=A), F_{\text {mean }}(=$ mean $)$ and $F_{\text {low }}(=B)$ are calculated from the MAXcurve of the advancing flow.

MNC 11/23 computer for further analysis. The indices were calculated from the maximum frequency curve (MAX-curve) which was derived off-line from the Doppler spectra. This MAXcurve represents the velocity of the fastest moving blood cells during the heart cycle (figure 2). Although the procedure in the determination of the MAX-curve of flow in vessels of adults is to process advancing and receding flow separately and to combine both MAX-curves afterwards to a single curve, we processed only the advancing MAX-curve since the umbilical vein is insonated frequently together with the umbilical artery.

The algorithm, by which the MAX-curves have been derived from the Doppler spectra, comprises local convolution of the spectra with a window which is 3 spectral lines wide and 5 frequency bits high and comprizes a $20 \mathrm{~Hz}$ FFT low-pass filtering of the MAX-curve. From the advancing MAX-curve the maximum fre- quency $\left(F_{\max }\right)$, the mean frequency $\left(F_{\text {mean }}\right)$ and the lowest frequency $\left(F_{\text {low }}\right)$ were calculatad from the first complete heart beat. The $F_{\max }$ was defined as the maximal value of the MAXcurve during the first heart beat (figure 2). The $F_{\text {mean }}$ was calculated from the onset of the first heart beat to the onset of the second heart beat in the spectrum (figure 2). The onset of a heartbeat was defined as the time, at which the MAX-curve showed a significant increase with respect to the pre-onset frequency for at least 5 consecutive spectral lines. The $F_{\text {low }}$ was calculated as the average value of the MAX-curve during 4 spectral lines (a period of $33.2 \mathrm{~ms}$ ) and 4 spectral lines $(33.2 \mathrm{~ms})$ prior to the onset of the second heart beat (figure 2).

$\mathrm{PI}, \mathrm{RI}$ and $\mathrm{A} / \mathrm{B}$ ratio were then calculated from $F_{\max }(=A), F_{\text {mean }}(=$ mean $)$ and $F_{\text {low }}(=B)$. The indices were correlated with the birthweights of the children. Small for gestational age (SGA) was defined as less than the 10th weight percen- 
tile of KLOOSTERMan [7]. The results of the appropriate for gestational age (AGA) group were compared with those of the SGA group.

The validity of the three indices in predicting IUGR was estimated by sensitivity and specificity (table I).

Furthermore, the Receiver Operating Characteristics (ROC curves) of the flow indices were plotted. ROC curves graphically visualize the effects of changes in the cut-off point on testsensitivity: on the vertical axis true-positive ratio (TPR) or sensitivity is plotted against falsepositive ratio (FPR) or specificity for various cut-off points on the horizontal axis [9]. Using these ROC curves, it is possible to compare our results in terms of sensitivity and specificity with those, reported by others.
At last we compared the results of the flow measurements of those pregnancies with fetal distress (as suspected by cardiotocography and resulting in a primary cesarean section) with those without fetal distress.

\section{Results}

Thirty-three patients were delivered of an AGA child and 15 patients were delivered of a SGA child. Table II presents some general data of the two groups. The high mean diastolic RR of the AGA group is due to the large number of patients in the studied group, admitted because of hypertension who nevertheless were delivered of an AGA child. Table III presents the mean value and standard deviation of the

Table I. Calculation of test-evaluation.

\begin{tabular}{llll}
\hline & & Outcome & \\
\cline { 3 - 4 } & & abnormal & normal \\
\hline Test & $\begin{array}{l}\text { abnormal } \\
\text { normal }\end{array}$ & $\begin{array}{l}\text { A (True positive) } \\
\text { C (False negative) }\end{array}$ & B (False positive) \\
\hline Sensitivity & & $: \mathrm{A} /(\mathrm{A}+\mathrm{C}) \times 100 \%$ & \\
Specificity & & $: \mathrm{D} /(\mathrm{B}+\mathrm{D}) \times 100 \%$ & \\
\hline
\end{tabular}

Table II. Study-group characteristics.

\begin{tabular}{|c|c|c|c|c|c|}
\hline \multirow[b]{2}{*}{ Number of patients } & \multicolumn{2}{|c|}{$\begin{array}{l}\text { Group SGA } \\
(<\mathrm{p} 10)\end{array}$} & \multicolumn{3}{|c|}{$\begin{array}{l}\text { Group AGA } \\
(\geqslant \mathrm{p} 10)\end{array}$} \\
\hline & 15 & & 33 & & \\
\hline Mean gestational age (and S. D.), when performing measurements (days) & 238 & $( \pm 7)$ & 242 & $( \pm$ & 7) \\
\hline Mean maximal diastolic RR (and S. D.) (mmHg) & 91.0 & $( \pm 11.1)$ & 87.2 & $( \pm$ & 11.8) \\
\hline Mean gestational age (and S. D.), at delivery (days) & 270 & $( \pm 14)$ & 271 & $( \pm$ & 11) \\
\hline Primary cesarean section (fetal distress) & 5 & & 2 & & \\
\hline \multicolumn{6}{|l|}{ Birthweight } \\
\hline - mean (and S. D.): & 2265 & $( \pm 465)$ & 3175 & $( \pm$ & 497) \\
\hline - frequency distribution: & 1 & & 0 & & \\
\hline $1000-1499 \mathrm{~g}$ & 3 & & 1 & & \\
\hline $1500-1999 \mathrm{~g}$ & 5 & & 2 & & \\
\hline $2000-24999 \mathrm{~g}$ & 6 & & 5 & & \\
\hline $2500-2999 \mathrm{~g}$ & 0 & & 25 & & \\
\hline$\geqslant 3000 \mathrm{~g}$ & & & & & \\
\hline Mean pH (and S. D.) of umbilical artery & 7.23 & $3( \pm 0.05)$ & 7.2 & $3( \pm$ & $0.06)$ \\
\hline
\end{tabular}

$\mathrm{SGA}=$ small for gestational age; $\mathrm{AGA}=$ appropiate for gestational age 
Table III. Mean value (and S.D.) of PI, RI and A/B ratio in the compared groups (SGA versus AGA).

\begin{tabular}{llll}
\hline & $\begin{array}{l}\text { SGA }(<\mathrm{p} \mathrm{10)} \\
(\mathrm{n}=15)\end{array}$ & $\begin{array}{l}\text { AGA }(\geqslant \mathrm{p} \mathrm{10)} \\
(\mathrm{n}=33)\end{array}$ & \\
\hline PI & $1.05(0.30)$ & $0.85(0.20)$ & $\mathrm{P}=0.04$ \\
RI & $0.63(0.10)$ & $0.57(0.08)$ & $\mathrm{P}=0.04$ \\
A/B ratio & $2.98(0.96)$ & $2.43(0.58)$ & $\mathrm{P}=0.04$ \\
\hline
\end{tabular}

three indices in both groups. The results of both groups were compared with the Mann-Whitney U-test. All three indices were significantly elevated in the SGA group as compared with the AGA group with a p-value of 0.04 for PI, RI and $A / B$ ratio. The correlations between the three indices were calculated. The Spearman correlation-coefficient of PI with RI was 0.995 and that of PI with $\mathrm{A} / \mathrm{B}$ ratio was 0.994 . The correlation coefficient of $\mathrm{RI}$ with the $\mathrm{A} / \mathrm{B}$ ratio was 0.998 . Figure 3 gives a graphical representation of the correlation between PI and A/B ratio.

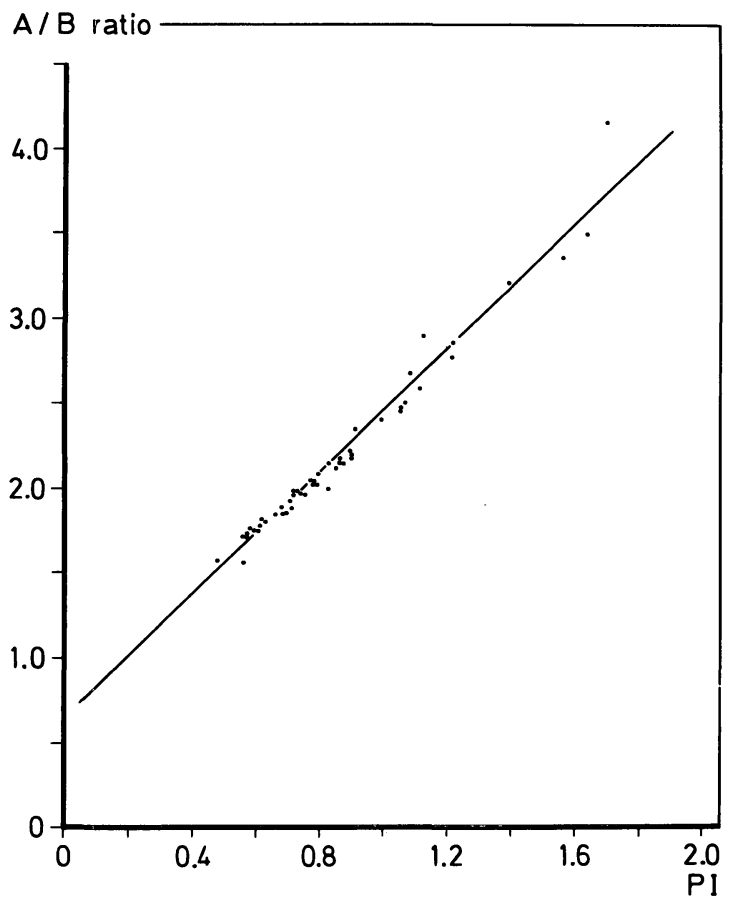

Figure 3. Grafical presentation of the correlation between $\mathrm{PI}$ and $\mathrm{A} / \mathrm{B}$ ratio. The Spearman correlationcoefficient of PI and A/B ratio was 0.994 .
The ROC curves of the $\mathrm{PI}$ and $\mathrm{A} / \mathrm{B}$ ratio are presented in the figures 4 and 5 . Figure 5 is presented in order to compare our results with

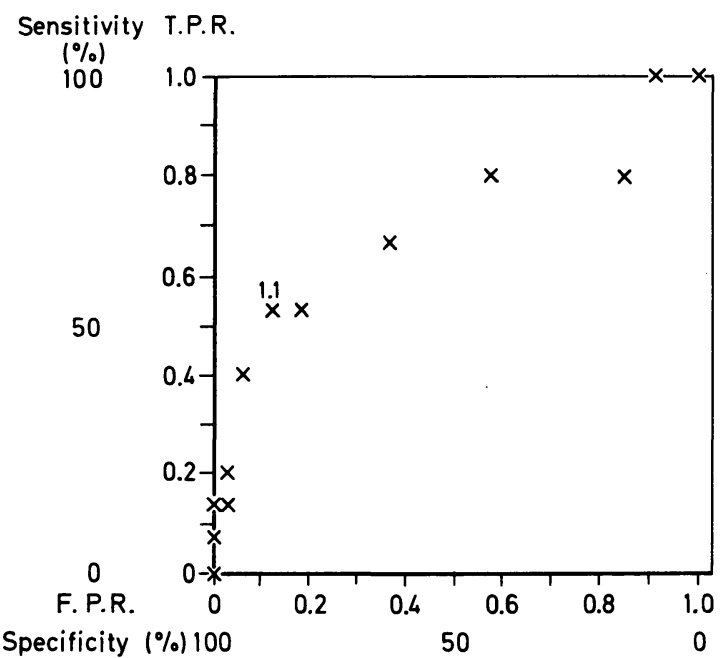

Figure 4. The ROC curve of the PI of the umbilical artery of the studied group. Changes in cut-off point (value of PI, discriminating between normal growth and IUGR) causes subsequent changes in sensitivity and specificity, or TPR and FPR. One cut-off point (PI = $1.1)$ is plotted in the curve.

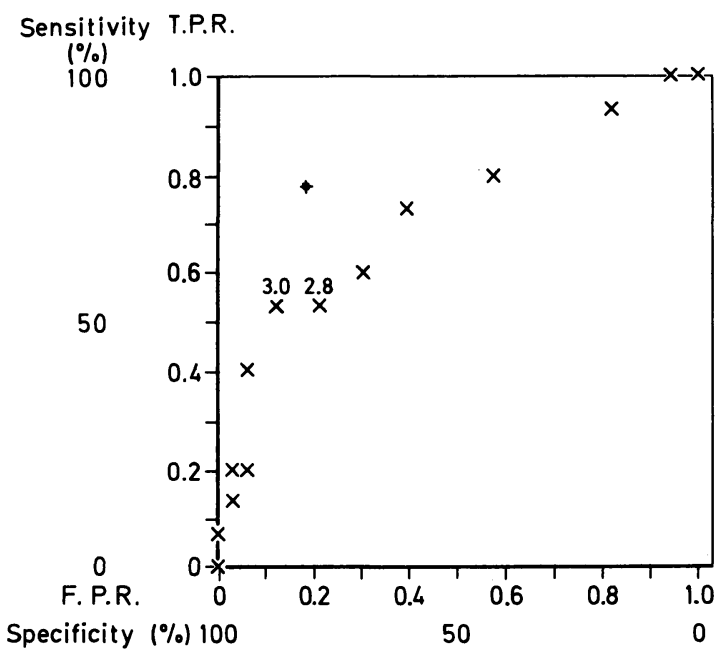

Figure 5. The ROC curve of the A/B ratio of the umbilical artery of the studied group. Note that the shape of the curve is equal to the curve of figure 4 due to the high correlation of both indices. The cut-off point of Fleischer $(\mathrm{S} / \mathrm{D}$ ratio $=3)$ is plotted in the curve $(+)$. Our corresponding A/B ratio is between 2.8 and 3.0, so comparable with the value of Fleischer. 
those, reported by FLEISCHER et al. [3], who used the $\mathrm{S} / \mathrm{D}$ ratio (or $\mathrm{A} / \mathrm{B}$ ratio) in their $\mathrm{FVW}$ analysis. Arbitrarily, sensitivity and specificity were calculated for the cut-off points $\mathrm{PI}=1.1$ and $\mathrm{A} / \mathrm{B}$ ratio $=3.0$. Choosing the discriminating PI of 1.1 a sensitivity of $53.3 \%$ with a specificity of $87.9 \%$ was found (table IV, figure $4)$; in case of the discriminating $\mathrm{A} / \mathrm{B}$ ratio of 3.0 the same number of true-positives, truenegatives, false-positives and false-negatives (with the sensitivity of $53.3 \%$ and specificity of $87.9 \%$, figure 5) were found.

Table IV. Evaluation of an increased PI $(\geqslant 1.1)$ in predicting SGA, at gestational age of $34 \pm 2$ weeks.

\begin{tabular}{lccc}
\hline & SGA $(<\mathrm{p} 10)$ & AGA $(\geqslant \mathrm{p} \mathrm{10)}$ & Totals \\
\hline PI $\geqslant 1.1$ & 8 & 4 & 12 \\
PI $<1.1$ & 7 & 29 & 36 \\
Totals & 15 & 33 & 48 \\
Sensitivity & $:$ & $53.3 \%$ & \\
Specificity & $:$ & $87.9 \%$ & \\
\hline
\end{tabular}

Regarding table IV, there were 4 patients with increased PI values, who nevertheless were delivered of a AGA child. One of them delivered of a child with Down syndrome (developing fetal distress some time after the flow measurements). Another patient had severe hypertension and also showed fetal distress some days later. For this reason we focused on fetal distress and tried to relate PI of the umbilical artery to it. The mean value of the PI of those pregnancies with fetal distress $(n=7)$ was 1.27 $( \pm 0.34)$, the mean PI of the those pregnancies without fetal distress $(\mathrm{n}=41)$ was 0.85 $( \pm 0.18)$. This difference is highly significant (U-test: $\mathrm{p}=0.005$ ).

\section{Discussion}

All three indices showed a significant difference in value between AGA and SGA children. The correlation between the indices appeared to be very high (close to one). There was no index, which discriminated significantly better between the presented groups than the other two.
For $\mathrm{RI}$ and $\mathrm{A} / \mathrm{B}$ ratio this is not suprising, since they can mathematically be expressed into each other as follows:

$$
\mathrm{RI}=(\mathrm{A}-\mathrm{B}) / \mathrm{A}=1-(\mathrm{A} / \mathrm{B} \text { ratio })^{-1} \text {. }
$$

According to this expression, the correlation between RI and A/B ratio has to be 1 and the Spearman-correlation coefficients of both PI with RI and PI with A/B ratio are essentially the same. So in the following part the study will be restricted to PI and A/B ratio.

One could speculate, that the PI should discriminate less consistently between normal and increased peripheral resistance than $\mathrm{RI}$ or $\mathrm{A} / \mathrm{B}$ ratio, since in the calculation of the PI the mean flow is also taken into account. The mean flow also depends on the frequency of the fetal heart (the higher the frequency, the higher the mean flow and the lower the PI). So PI values will fluctuate more than the other two indices because of the well-known fluctuations in fetal heart rate. This disadvantage of the PI is less pronounced when measuring in a steady state of the fetus (no gross body movements with subsequent fetal heart rate accelerations). On the other hand, the PI can be more accurate since this index is destined by the complete waveform, while in the calculation of the A/B ratio (or RI) only peak-systolic and end-diastolic levels are taken into account. This means, that in case of changes in the shape of the waveform (by elevated resistance downstream without decreased end-diastolic flow level) these changes are reflected in the value of PI and not in the value of $\mathrm{A} / \mathrm{B}$ ratio (or $\mathrm{RI}$ ).

Despite these considerations we could not find a difference between the indices in predicting eventual growth retardation; on the contrary: the correlation was high, and no arguments were found to prefer one index above the other.

In relation to the clinical relevance of predicting growth retardation, to our knowledge only FLEISCHER et al. [3] have analyzed their results in terms of sensitivity and specificity. They choose a discriminating value of their $S / D$ ratio of 3.0. Their reported specificity of $83.3 \%$ was some what less than our value of $87.9 \%$, al- 
though this difference was not significant $\left(\chi^{2}\right.$ test: $\mathrm{p}=0.80)$. The sensitivity, reported by FLEISCHER (78.3\%) was higher than the sensitivity in this study (53.3\%); however also this difference was not significant $\left(\chi^{2}\right.$ test: $\mathrm{p}=$ 0.20 ).

In the ROC curve of our A/B ratio (figure 5) we also plotted the cut-off point of FLEISCHER $(\mathrm{S} / \mathrm{D}$ ratio $=3.0)$. With a comparable specificity, our flow measurements have a sensitivity of $\pm 53 \%$ in predicting subsequent growth retardation. The discriminating value of our $\mathrm{A} / \mathrm{B}$ ratio is between 2.8 and 3.0.

Analyzing our results, the sensitivity of the PI of the umbilical artery in predicting growth retardation with an acceptable specificity is rather disappointing. With a specificity of $87.9 \%$, only one out of two fetuses will be predicted to be growth retarded.

In our opinion a diagnostic test, i.e. FVW analysis of the umbilical artery for prediction of IUGR should be analyzed preferably by ROC analysis. Changes in cut-off point with subsequent changes in sensitivity and specificity should be evaluated; these changes can be visualized in the ROC curve. In this respect the aim of the test is particularly important. When introducing a new test into antenatal care, one should consider the consequences of demanding a high sensitivity or specificity.

These preliminary results show that, at a gestational age of $34 \pm 2$ weeks, FVW analysis of

\section{Summary}

The literature reporting Doppler ultrasound flow velocity waveform analysis of the umbilical artery and its applications for detecting intrauterine growth retardation (IUGR) is growing rapidly. Several indices originally introduced to evaluate different vascular beds in adults, are used to assess the vascular bed resistance downstream the umbilical artery (i. e. the placental bed). A higher resistance in this placental bed causes a decreased end-diastolic flow, which is described in combination with IUGR. The three most commonly used flow indices are: $\mathrm{A} / \mathrm{B}$ ratio, Resistance Index $(\mathrm{RI}=(\mathrm{A}-\mathrm{B}) /$ $\mathrm{A})$ and Pulsatility Index $(\mathrm{PI}=(\mathrm{A}-\mathrm{B}) /$ mean $)$.

In this study we evaluated which of these indices correlated best with IUGR. We calculated the three above the umbilical artery probably is not more effective in the prediction of the IUGR than physical examination in combination with ultrasound measurements of the fetus $[14,15]$.

Growth retardation may have many causes. Not in all circumstances there is diminished fetal placental circulation, causing fetal growth retardation. IUGR can also be explained as a manifestation of congenital fetal dysfunction, congenital infectious disease, or it can be constitutional, as the result of a small father/small mother interaction $[14,15]$. In this last case, the fetus is not supposed to be at risk and will have normal fetal placental circulation, indicated by a normal PI of the umbilical artery. From this point of view, a low sensitivity of the umbilical artery flow measurements in predicting IUGR can be partially explained (table IV: 7 SGA children with PI $<1.1$ ). The preliminary results concerning PI of the umbilical artery and fetal distress may indicate, that there is a better relation with the development of fetal-distress later on in pregnancy. Indeed, a growth retarded fetus is at risk for developing fetal distress, but also a AGA fetus can develop distress, i. e. when there is a diminished utero-placental flow in case of (severe) hypertension at the end of pregnancy.

Perhaps the clinical use of flow measurements of the umbilical artery may be more valuable in predicting fetal distress than in predicting growth retardation.

mentioned indices from the same recordings of the blood flow (at a gestational age of $34 \pm 2$ weeks) and correlated the results with the subsequent birthweight of the child. In the studied group $(n=48) 15$ children were small for gestational age (SGA $=<\mathrm{P} 10)$ and 33 children were appropriate for gestational age $(\mathrm{AGA}=$ $\geqslant P$ 10).

All three indices showed a significant difference in value between AGA and SGA children (see table III). The Spearman correlation-ceofficients were calculated and were approximately one. So there was a high correlation between all three indices. This indicates that the different indices have the same relation to IUGR. Thus, no arguments were found to prefer one index above the other. 
In the second part of the study we investigated the validity of these indices to predict IUGR. The validity can be estimated from two components: the sensitivity and specificity. Both sensitivity and specificity are determined by the value of the index which discriminates between AGA and SGA. Changes in this discriminating value (the so-called cut-off point) will change both sensitivity and specificity. This last effect can be visualized in the Receiver-Operating-Characteristic (ROC) curve, which plots sensitivity against specificity for different cut-off points (see figures 4 and 5). Arbitrarily sensitivity and specificity were calculated for the cut-off points PI $=1.1$ and $\mathrm{A} / \mathrm{B}$ ratio $=3.0$. Choosing these cut-off points, the same specificity of $87.9 \%$ with a sensitivity of $53.3 \%$ were found (table IV). It is concluded, that the sensitivity of the PI of the umbilical artery in predicting growth retardation with acceptable specificity is rather disappointing. A possible reason for this is discussed. Growth retardation may have many causes. Not in all circumstances there is a diminished fetal placental circulation, i.e. in case of the constitutionally small fetus (small mother/small father interaction). This fetus is not supposed to be at risk and will have normal fetal placental circulation.

We also compared our results of specificity and sensitivity with the results reported by FLEISCHER et al. [3], who also have analyzed the validity of their flow measurements. For that reason also the ROC curve made up by the different A/B ratio's of the studied group is presented and in this curve FLEISCHER's cut-off point (S/D ratio $=3.0$ ) with the reported sensitivity of $78 \%$ and specificity of $83 \%$ was plotted (figure 5).

Our sensitivity was $\pm 53 \%$ by choosing a comparable specificity of $83 \%$, so lower than the sensitivity of $78 \%$ reported by FLEISCHER. This difference was however not significant $\left(\chi^{2}\right.$ test: $\left.p=0.20\right)$ due to the small groups in both studies. With this specificity of $83 \%$ the discriminating value of our A/B ratio was between 2.8 and 3.0, so comparable with FLEISCHER's S/D ratio of 3.0 (figure 5).

Because of the disappointing sensitivity for predicting IUGR we also related one of the three indices (PI) of the umbilical artery to fetal distress (as suspected by cardiotocography and resulting in a primary sesarean section). The mean PI of those pregnancies with fetal distress $(\mathrm{n}=7)$ was $1.27( \pm 0.34)$, the mean PI of those without fetal distress $(n=41)$ was $0.85( \pm 0.18)$. This difference was highly significant $(p=0.005)$.

From these first results it may perhaps be concluded, that the clinical use of flow measurements of the umbilical artery may be perhaps more valuable in predicting fetal distress than in predicting IUGR.

Keywords: A/B-ratio, Doppler ultrasound, growth retardation, Pulsatility Index, Resistance Index, umbilical artery.

\section{Zusammenfassung}

Vergleich von drei Indizes der umbilikalen Flow-Messung bezüglich ihrer Aussagekraft bei der Diagnostik einer intrauterinen Wachstumsretardierung

Die Literatur zum Thema Flow-Geschwindigkeitskurven in der Umbilikalarterie und ihre Verwertbarkeit zur Diagnostik einer intrauterinen Wachstumsretardierung (IUGR) ist inzwischen sehr umfangreich. Einige Indizes, die ursprünglich zur Beschreibung unterschiedlicher Gefäße beim Erwachsenen dienten, werden eingesetzt, um den Gefäßwiderstand entlang der Umbilikalarterie, speziell in der Plazenta zu bestimmen. Ein hoher Widerstand in der Plazenta führt $\mathrm{zu}$ einem herabgesetzten enddiastolischen Flow, wie er in Kombination mit einer IUGR beschrieben wird. Die 3 gebräuchlichsten Indizes sind: $\mathrm{A} / \mathrm{B}-$ Ratio, Widerstands-Index $[\mathrm{RI}=(\mathrm{A}-\mathrm{B}) / \mathrm{A}]$ und Pulsatilitäts-Index [PI $=(\mathrm{A}-\mathrm{B}) /$ mean].

In dieser Studie wurde untersucht, welcher dieser drei Indizes am besten mit einer IUGR korreliert. Bei einem Gestationsalter von $34 \pm 2$ Wochen wurde die FlowMessung vorgenommen und die 3 oben beschriebenen Indizes berechnet. Nach der Entbindung wurden dann Indizes und Geburtsgewicht miteinander korreliert. In dem Untersuchungskollektiv $(\mathrm{n}=48)$ waren 15 hypotrophe $(P<10)$ und 33 eutrophe Kinder $(P \geqslant 10)$.

Die Indizes der hypotrophen und eutrophen Kinder unterschieden sich signifikant (Tabelle III). Der Spearmansche Korrelationskoeffizient wurde berechnet und betrug nahezu 1, was auf eine hohe Korrelation aller 3 Indizes hinweist; $d$. h.: die 3 verschiedenen Indizes haben die gleiche Aussagekraft bezüglich einer IUGR.

Im zweiten Teil dieser Untersuchung wurde die Validität dieser Indizes bestimmt. Sie läßt sich aus 2 Komponenten abschätzen: Sensitivität und Spezifität. Beide Parameter werden über den Indexwert bestimmt, der zwischen Eutrophie und Hypotrophie unterscheidet. Abweichungen von diesem sogenannten Cut-off Point verändern sowohl die Sensivität wie auch die Spezifität. Dies kann in einer bestimmten mathematischen Charakteristik dargestellt werden, in der die Sensitivität gegenüber der Spezifität für verschieden Cut-off Points aufgetragen wird (Abb. 4 und 5). Für die willkürlich gewählten Cutoff Points PI = 1.1 und A/B-Ratio = 3.0 wurden die Sensitivität und Spezifität berechnet. Wenn man diese Cut-off Points wählt, findet man eine Spezifität von $87.9 \%$ und eine Sensitivität von $53.5 \%$ (Tabelle IV).

Man muß daraus schließen, daß die Sensitivität der Methode, über den PI der Umbilikalarterie eine Wachstumsretardierung mit einer akzeptablen Spezifität vorauszusagen, ziemlich gering ist. Eine mögliche Ursache wird diskutiert. Die Wachstumsretardierung kann verschiedene Gründe haben. Nicht in allen Fällen ist die fetale plazentare Zirkulation vermindert, so z. B. beim konstitutionell kleinen Feten (Interaktion bei kleinwüchsiger Mutter/kleinwüchsigem Vater). Für diese Feten 
liegt kein erhöhtes Risiko vor und die fetale plazentare Zirkulation ist normal.

Unsere Ergebnisse bezüglich der Spezifität und Sensitivität haben wir mit denen von FLEISCHER et al. [3] verglichen, die ebenfalls die Validität ihrer Flow-Messungen analysiert haben. Die mit den unterschiedlichen A/BRatio-Werten unseres Untersuchungskollektivs aufgestellte Charakteristik wurde verwendet und darin der von FleISCHER gefundene Cut-off Point (S/D-Ratio = 3.0) mit der von ihm beschriebenen Sensitivität von $78 \%$ und Spezifität von $83 \%$ aufgetragen (Abb. 5).

Bei einer vergleichbaren Spezifität von $83 \%$ war unsere Sensitivität mit $\pm 53 \%$ niedriger als die von FLEISCHER angegebene Sensitivität von $78 \%$. Wegen der kleinen Fallzahl in beiden Gruppen war dieser Unterschied jedoch nicht statistisch signifikant $\left(\chi^{2}\right.$-Test: $\left.p=0.20\right)$. Mit dieser Spezifität von $83 \%$ lag der Cut-off Point unserer A/B-Ratio zwischen 2.8 und 3.0 und war somit vergleichbar mit der von FLeISCHER angegebenen S/DRatio von 3.0 (Abb. 5).

Da die Sensitivität hinsichtlich der Voraussage einer IUGR sehr niedrig war, haben wir untersucht, ob einer der 3 Indizes (PI in der Umbilikalarterie) positiv mit einem fetalen Distress (laut kardiotokographischem Befund und einer primären Sectio als Konsequenz) korreliert. Der mittlere PI bei Schwangerschaften mit Verdacht auf ein fetales Distress $(\mathrm{n}=7)$ betrug 1.27 $( \pm 0.34)$, bei Schwangerschaften ohne Komplikationen $(\mathrm{n}=41) 0.85( \pm 0.18)$. Der Unterschied ist statistisch hochsignifikant $(\mathrm{p}=0.005)$.

Diese ersten Ergebnisse lassen vermuten, daß der klinische Nutzen von Flow-Messungen in der Umbilikalarterie eher auf dem Gebiet der Diagnostik eines fetalen Distress als einer IUGR liegt.

Schlüsselwörter: A/B-Ratio, Dopplersonographie, Pulsatilitäts-Index, Umbilikalarterie, Wachstumsretardierung, Widerstands-Index.

\section{Résumé}

Etude comparative de trois indices du débit sanguin ombilical avec la prédiction du retard de croissance

La littérature concernant l'analyse des ondes de vélocité sanguine par effets doppler au niveau de l'artére ombilicale ainsi que ses applications pour la détection du retard de croissance intrautérin (RCIU) se développe rapidement. Plusieurs indices, primitivement proposés pour étudier différents lits vasculaires chez l'adulte, sont utilisés pour déterminer les résistances vasculaires au niveau de l'artère ombilicale (c'est-à-dire le lit placentaire). Des résistances élevées au niveau placentaire entraînent une diminution du flux télédiastolique, diminution décrite comme assciée au RCIU. Les trois indices les plus couremment utilisés sont: le rapport $\mathrm{A} / \mathrm{B}$, l'index de résistance $(I R=(A-B) / A)$ et l'index de pulsatilité $(\mathrm{IP}=(\mathrm{A}-\mathrm{B}) /$ moyenne $)$.

Dans cette étude nous avons évalué lequel de ces indices est corrélé le mieux avec le RCIU. Nous avons calculé les trois indices mentionnés ci-dessus à partir des mêmes enregistrements du débit sanguin (à un âge gestationnel de $34 \pm 2$ semaines) et nous avons corrélé les résultats avec les poids de naissance correspondants des enfants. Dans le groupe étudié $(\mathrm{n}=48), 15$ enfants étaient hypotrophiques (hypotrophie $=<10^{\circ}$ percentile), 33 enfants étaient entrophiques $\left(\geqslant 10^{\circ}\right.$ percentile).

Les trois indices montrent une différence significative entre les valeurs des enfants hypotrophiques et celles des enfants eutrophiques (voir tableau III). On a calculé les coefficients de corrélation de Spearman, ils sont approximativement de 1 . Ainsi, il y a une corrélation élevée entre les trois indices. Ceci signifie que les différents indices sont également corrélés au RCIU. Ainsi, il n'a pas été trouvé d'arguments pour préférer un index par rapport aux autres.

Dans la seconde partie de notre étude, nous avons exploré la validité de ces indices pour prédire le RCIU.
On peut apprécier la validité à partir de la sensibilité et à partir de la spécificité. On détermine la sensibilité et la spécificité par la valeur de l'index qui permet de distinguer entre hypotrophie et eutrophie. Les variations de cette valeur discriminative modifieront et la sensibilité et la spécificité. On peut visualiser ce dernier effet sur une courbe qui exprime la sensibilité à l'opposé de la spécificité pour les différents points de discrimination (voir figures 4 et 5 ). De façon arbitraire, on a calculé la sensibilité et la spécificité pour les points de discrimination suivants: IP $=1,1$ et rapport $\mathrm{A} / \mathrm{B}=3$. En choississant ces points, on a trouvé la même spécificité de $87,9 \%$ avec une sensibilité de 53,5\% (tableau IV).

On en conclut que la sensibilité de l'IP dans l'artère ombilicale pour prévoir un retard de croissance avec une spécificité acceptable est plutôt décevante. On en discute une raison possible. Le retard de croissance peut avoir de nombreuses causes. Il n'y a pas de diminution de la circulation fotoplacentaire dans toutes les situations, par exemple en cas d'hypotrophie constitutionnelle (interaction petite mère/petit père). On ne peut pas considérer ce fotus comme étant à risque et il a une circulation fœto-placentaire normale.

Nous avons également compáré nos résultats concernant la spécificité et la sensibilité avec les résultats de FLEISCHER et al. [3] qui ont également analysé la validité de leurs mesures de débit. Pour cette raison nous avons présenté les courbes concernant les différents rapports A/B du groupe étudié et nous avons fait figurer sur cette courbe les points de discrimination de FleISCHER (rapport $\mathrm{S} / \mathrm{D}=3$ ) avec une sensibilité rapportée de $78 \%$ et une spécificité de $83 \%$ (figure 5 ).

En choississant une spécificité comparable de $83 \%$ notre sensibilité est de $53 \%$, plus faible que la sensibilité de $78 \%$ rapportée par FLEISCHER. Toutefois, cette différence n'est pas significative (test de $\left.X^{2}: p=0,2\right)$ du fait 
des petits échantillons dans les deux études. Avec cette spécificité de $83 \%$ les valeurs discriminatives de notre rapport $\mathrm{A} / \mathrm{B}$ sont comprises entre 2,8 et 3, comparables au rapport S/D de FLeischer: 3 (figure 5).

En raison d'une sensibilité décevante dans la prédiction du RCIU, nous avons également corrélé un des trois indices (IP) de l'artère ombilicale avec la souffrance fotale (suspectée sur la cardiotocographie et ayant entraîné une césarienne systématique). L'IP moyen de ces grossesses avec souffrance fœtale $(n=7)$ est de 1,27 $( \pm 0,34)$, l'IP moyen des grossesses sans souffrance fœtale $(n=41)$ est de $0,85( \pm 0,18)$. Cette différence est hautement significative $(\mathrm{p}=0,005)$. Sur la base de ces premiers résultats, on peut peut-être conclure que l'utilisation clinique des mesures du flux sanguin de l'artère ombilicale est peut-être plus valable pour prévoir la souffrance fætale que pour prévoir le RCIU.

Mots-clés: Artère ombilicale, échographie doppler, index de pulsatilité, index de résistance, rapport A/B, retard de croissance.

\section{References}

[1] Campbell S, CJ Hernandez, TA Cohen-OverBEEK, JMF PEARCE: Assessment of fetoplacental and uteroplacental blood flow using duplex pulsed Doppler ultrasound in complicated pregnancies. J Perinat Med 12 (1984) 262

[2] FitzGerald DE, B Stuart, JE Drumm, NM DuigNAN: The assessment of the feto-placental circulation with continuous wave Doppler ultrasound. Ultrasound Med Biol 10 (1984) 371

[3] Fleischer A, H Schulman, G Farmakides, L BraCERO, P BLATTNER, G RANDOLPH: Umbilical artery velocity waveform and intrauterine growth retardation. Am J Obstet Gynecol 151 (1985) 502

[4] GosLing RC, DH KING: Continuous wave ultrasound as an alternative and complement to X-rays in vascular examinations. In: RENEMAN RS (ed): Cardiovascular Applications of Ultrasound, pp 266. North-Holland/American Elsevier, New York 1974

[5] GosLING RC: Extraction of physiological information from spectrum analysed Doppler-shifted continuous wave ultrasound signal obtained non-invasively from the arterial tree. In: Hill DM, BW WATSON (eds): IEE Medical Electronic Monographs 13-22, pp 73. Peter Peregrinus, London 1976

[6] Griffin D, K Bilardo, L Masini, J Diaz-RecaSENS, JM Pearce, K Wilson, S Campbell: Doppler bloodflow waveforms in the descending thoracic aorta of the human fetus. Br J Obstet Gynaecol 91 (1984) 997

[7] Kloosterman GJ: On intrauterine growth. Int J Obstet Gynaecol 8 (1970) 895

[8] Marsal K, SH Eik-Nes, A Lindblad, G Lingman: Bloodflow in the fetal descending aorta. Intrinsic factors affecting fetal blood flow. Ultrasound Med Biol 10 (1984) 339

[9] MCNeIl BJ, SJ Adelstein: Determining the value of diagnostic and screening tests. J Nucl Med 17 (1976) 439

[10] Pourcelot L: Applications cliniques de l'examen Doppler transcutane. In: Peroneau P (ed): Velocimetric ultrasonor Doppler. Inserm 34 (1974) 213.
[11] ReuWer PJHM, WC NuYen, HJM Beyer, RM HeEthaAR, HW Bruinse, P Stoutenbeek, AA HaSPELS: Characteristics of flow velocities in the umbilical arteries, assessed by Doppler ultrasound. Eur J Obstet Gynecol Reprod Biol 17 (1984) 397

[12] ReUWER PJHM, HW BRUINSE, P STOUTENBEEK, AA HASPELS: Doppler assessment of the fetoplacental circulation in normal and growth-retarded fetuses. Eur J Obstet Gynecol Reprod Biol 18 (1984) 199

[13] Schulman H, A Fleischer, W Stern, G FarmaKIDES, N JAGANI, P BLATTNER: Umbilical velocity wave ratios in human pregnancy. Am J Obstet Gynecol 148 (1984) 985

[14] SEEDS JW: Impaired fetal growth: Definition and clinical diagnosis. Obstet Gynecol 64 (1984) 303

[15] SEEDS JW: Review: Impaired fetal growth: Ultrasonic evaluation and clinical management. Obstet Gynecol 64 (1984) 577

[16] Stuart B, J Drumm, D Fitzgerald, NM DuigNAN: Fetal blood velocity waveforms in normal pregnancy. Br J Obstet Gynaecol 87 (1980) 780

[17] Trudinger BJ, WB Giles, CM COOK, J BombardiERI, L COLLINS: Fetal umbilical artery flow velocity waveforms and placental resistance: clinical significance. Br J Obstet Gynaecol 92 (1985) 23

[18] Trudinger BJ, WB Giles, CM CoOK: Flow velocity waveform in the maternal uteroplacental and fetal umbilical placental circulations. Am J Obstet Gynecol 152 (1985) 155

[19] WiJn PFF, P VAN DER SAR, THJM GoOTZEN, MJH Tilmans, SH SkotNickr: The value of the spectral broadening index in continous wave Doppler measurements. Med Biol Eng Comp (submitted)

Received November 11, 1985. Revised March 25, 1986. Accepted April 24, 1986.

\section{Léon G. M. Mulders}

Department of Obstetrics and Gynecology

St. Radboud Hospital

P. O. Box 9101

6500 HB Nijmegen

The Netherlands 